\title{
THE NUCLEAR DEHYDROGENATION OF STEROIDS BY INTESTINAL BACTERIA
}

\author{
P. Goddard, Fresia Fernandez, Beryl West, M. J. Hill and P. Barnes* \\ Bacterial Metabolism Research Laboratory, Colindale, London NW9 $5 D X$, and \\ * Department of Chemistry, Liverpool Polytechnic, Liverpool L3 3 AF
}

WE have postulated that bacteria may play a vital role in the aetiology of cancer of the colon (Aries et al., 1969; Hill et al., 1971) by producing a carcinogen or co-carcinogen from dietary components or from intestinal secretions. Our work has concentrated on the possibility that gut bacteria might produce such an agent, possibly a polycyclic aromatic hydrocarbon, from the bile acids; this would theoretically require only four types of nuclear dehydrogenation (NDH) reaction (Hill, 1970) and we have now demonstrated all four with human gut bacteria (Aries, Goddard and Hill, 1971; Goddard and Hill, 1972, 1973). Of these, the 6-7 dehydration reaction-which is a manifestation of the 7adehydroxylation reaction-is carried out by non-sporing strictly anaerobic bacteria; the other three reactions have been demonstrated in preliminary studies with lecithinase-negative clostridia.

In the work described in the present paper we have extended our screening studies and have demonstrated that the three latter nuclear dehydrogenations (figure) are carried out by a small proportion of strains of Clostridium welchii, a high proportion of strains of $C$. paraputrificum and closely related strains, but by no organisms of various other genera tested.

\section{MATERIALS AND METHODS \\ Bacteriological procedures}

All strains tested in our screening studies were isolated by the methods of Drasar and Crowther (1970) from British and American samples of faeces unless otherwise stated. The non-sporing strictly anaerobic organisms were characterised by the methods of Peach $e t$ al. (1974). Clostridia were characterised by a method based on that described by Holdeman and Moore (1972); these methods will be fully described by Drasar et al. (1976). The aerobic organisms (Escherichia coli and Streptococcus faecalis) were identified by the methods of Cowan and Steel (1965).

\section{Assay of nuclear dehydrogenases}

The assay of cholanoyl $\Delta^{4}$-dehydrogenase (reaction A) was described by Aries $e t$ al. (1971) with $5 \beta$-androstan-3,17-dione as the substrate. The aromatisation of ring $A$ of 4-androsten-3,17-dione (reaction B) was assayed by the method described by Goddard and Hill (1972). The formation of equilenin (reaction C) was assayed by the method of Goddard and Hill (1973) based on that of Sehgal and Vezina (1970).

Received 8 Aug. 1974; revised version accepted 24 Feb. 1975. 


\section{RESULTS}

In all, 1095 strains were tested for their ability to produce $\Delta^{4}$-dehydrogenase (reaction A) and 853 were tested for the aromatisation of 4-androsten-3,17dione (reaction B) (table I). The collection included 100 strains of Escherichia coli, 100 of Streptococcus faecalis and 100 of Bacteroides fragilis. The Bifidobacterium spp. were Bif. bifidum (19 strains), Bif. adolescentis (49 strains) and Bif. eriksonii (7 strains), and the Eubacterium spp. were Eub. aerofaciens (22

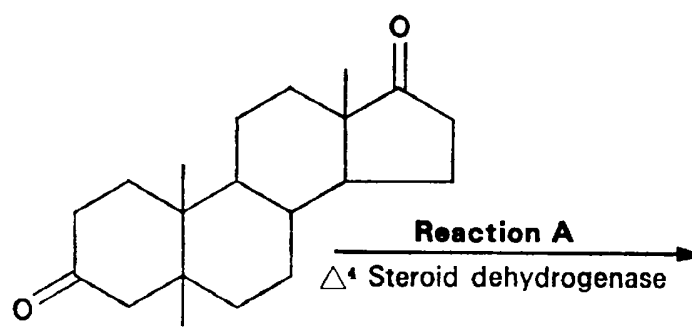

$5 \beta$-Androstan-3,17-dione<smiles>CC12CCC3C(CCC4=CC(=O)CCC43C)C1CCC2=O</smiles>

4. Androsten-3,17- dione

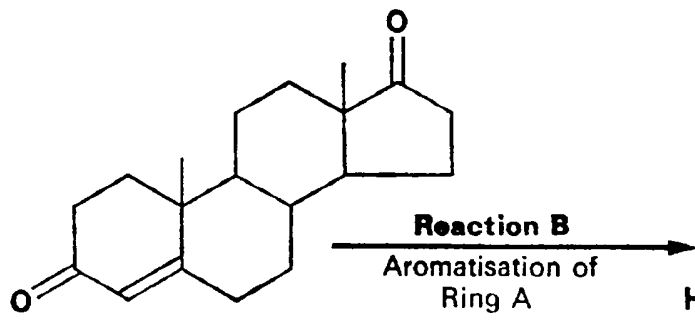

4-Androsten -3,17-dione

17-methoxy $-1,3,5,(10)$ - cestratrien-3-ol<smiles>CC12CCC3c4ccc(O)cc4C=CC3C1CCC2=O</smiles>

3-Hydroxy-1,3,5, (10),6-oestratetren-17-one (equilin)
3-Hydroxy-1,3,5(10)6,8,(9)-oestrapenten-17-one (equilenin)

Figure.-Mechanisms by which the intestinal bacteria dehydrogenate the steroid nucleus.

Reaction $A$. Dehydrogenation in conjugation with a 3-oxo group. 5 5 -Androstan-3,17-dione is converted to 4-androsten-3,17-dione by the enzyme $\Delta^{4}$-steroid dehydrogenase.

Reaction B. Removal of the 10-methyl group; this is accompanied by a C1-2 dehydrogenation resulting in the aromatisation of ring $A$ to give oestradiol from 4-androsten-3,17-dione. The product obtained is normally 17 -methoxyoestradiol and this indicates that the 10-methyl group is transferred to the 17-position.

Reaction $C$. Introduction of a double bond conjugated to other double bonds. This is demonstrated by the production of 3-hydroxy-oestra-1,3,5(10),6,8(9)-penten-17-one (equilenin) from 3-hydroxy-oestra-1,3,5(10),6-tetren-17-one (equilin) by the action of the enzyme $\Delta^{8}$ dehydrogenase. Equilin is the product of reaction $B$ on 4,6-androstadiene-3,17-dione. 
strains) and Eub. lentum (3 strains). All of the above strains were unable to bring about reaction A or B, as were all of the 100 strains of Clostridium bifermentans that we tested. However, 3 of 100 isolates of $C$. welchii carried out both reactions $\mathbf{A}$ and $\mathbf{B}$.

In early studies (Aries et al., 1971; Goddard and Hill, 1972) we found that both reactions $\mathrm{A}$ and $\mathrm{B}$ were carried out by strains of lecithinase-negative clostridia and so large numbers of such strains were tested (table I). A very large proportion of strains of $C$. paraputrificum both produced the $\Delta^{4}$-dehydrogenase and aromatised the product of that reaction. In addition, a large proportion of strains of $C$. tertium and almost one-third of strains of $C$. indolis produced both enzymes, but only a small proportion of other species did so; the latter included C. rectum (2 of 19 strains), C. felsinium (2 of 32 strains), C. cadaveris ( 2 of 23 strains), C. chauvoei (2 of 35 strains), C. sartagoformium (4 of 31 strains), C. stricklandii (1 of 16 strains), C. innocuum (1 of 10 strains) and 11 of 148 strains of a further 19 species.

All strains able to aromatise 4-androsten-3,17-dione were also able to form

TABLE I

The ability of bacteria to produce $\Delta^{4}$-dehydrogenase (reaction $A$ ) and to aromatise the product of that reaction (reaction $B$ )

\begin{tabular}{|c|c|c|c|c|}
\hline \multirow[b]{2}{*}{ Test organisms } & \multicolumn{2}{|c|}{ Reaction A } & \multicolumn{2}{|c|}{ Reaction B } \\
\hline & $\begin{array}{c}\text { Number } \\
\text { tested }\end{array}$ & $\begin{array}{l}\text { Percentage } \\
\text { number } \\
\text { positive }\end{array}$ & $\begin{array}{c}\text { Number } \\
\text { tested }\end{array}$ & $\begin{array}{l}\text { Percentage } \\
\text { number } \\
\text { positive }\end{array}$ \\
\hline $\begin{array}{l}\text { Gram-negative non-spori } \\
\text { anaerobes: } \\
\text { Bacteroides fragilis }\end{array}$ & 100 & 0 & 100 & 0 \\
\hline $\begin{array}{l}\text { Gram-positive non-spori } \\
\text { anaerobes: } \\
\text { Bifidobacterium spp. } \\
\text { Eubacterium spp. }\end{array}$ & $\begin{array}{l}75 \\
25\end{array}$ & $\begin{array}{l}0 \\
0\end{array}$ & $\begin{array}{l}75 \\
25\end{array}$ & $\begin{array}{l}\mathbf{0} \\
\mathbf{0}\end{array}$ \\
\hline $\begin{array}{l}\text { Aerobes: } \\
\text { Escherichia coli } \\
\text { Streptococcus faecalis }\end{array}$ & $\begin{array}{l}100 \\
100\end{array}$ & $\begin{array}{l}0 \\
0\end{array}$ & $\begin{array}{l}100 \\
100\end{array}$ & $\begin{array}{l}0 \\
0\end{array}$ \\
\hline $\begin{array}{l}\text { Lecithinase-positive spori } \\
\text { anaerobes: } \\
\text { Clostridium welchii } \\
\text { C. bifermentans }\end{array}$ & $\begin{array}{l}100 \\
100\end{array}$ & $\begin{array}{l}3 \\
0\end{array}$ & $\begin{array}{l}100 \\
100\end{array}$ & $\begin{array}{l}3 \\
0\end{array}$ \\
\hline $\begin{array}{l}\text { Lecithinase-negative spor } \\
\text { anaerobes: } \\
\text { C. paraputrificum } \\
\text { C. indolis } \\
\text { C. tertium } \\
\text { Others }\end{array}$ & $\begin{array}{r}112 \\
49 \\
20 \\
314\end{array}$ & $\begin{array}{r}93 \\
31 \\
90 \\
8\end{array}$ & $\begin{array}{r}69 \\
29 \\
0 \\
155\end{array}$ & $\begin{array}{l}87 \\
31 \\
\cdots \\
4\end{array}$ \\
\hline Total number tested & 1095 & ... & 853 & $\cdots$ \\
\hline
\end{tabular}


that substrate from $5 \beta$-androstan-3,17-dione, but there were strains able to perform reaction $A$ that were unable to carry on to the next stage.

In our experience with intestinal bacteria as the test organisms, the plate method for testing the production of equilin and equilenin was quite unreliable; this contrasts with the experience of Sehgal and Vezina (1970) who worked with soil organisms. Much more work is necessary before this plate method could be used for rapid screening of strains. To date, no strain has been found to carry out reaction $C$ that did not also produce the enzymes for reactions $A$ and $B$; the converse is not true. In view of our reservations concerning the test for the products of reaction $\mathrm{C}$, only 20 strains of $C$. paraputrificum have been tested so far; all 20 were able to carry out reactions $A$ and $B$, and only 5 were positive for reaction C. No strains of other genera produced equilenin, but this result may not be significant until we can be sure that the assay conditions are adequate.

The occurrence of NDH clostridia in human faeces

Lecithinase-negative clostridia were isolated from faeces of people living in England, Scotland, Uganda and Hong Kong; the populations studied were those described previously by Hill et al. (1971). The classification of these organisms has proved extremely complex and will be the subject of another communication; at present we have identified the organisms of immediate

\section{TABLE II}

The ability of lecithinase-negative clostridia isolated from faeces of people from four countries to dehydrogenate the steroid nucleus (reaction A)

\begin{tabular}{l|cc}
\hline $\begin{array}{c}\text { Country of origin } \\
\text { and strains tested }\end{array}$ & $\begin{array}{c}\text { Number of strains } \\
\text { tested }\end{array}$ & $\begin{array}{c}\text { Percentage number } \\
\text { able to dehydrogenate } \\
\text { the steroid nucleus }\end{array}$ \\
\hline \begin{tabular}{l|l} 
Scotland \\
All strains
\end{tabular} & 67 & 44 \\
C. paraputrificum & 27 & 93 \\
C. indolis & 8 & 63 \\
Others & 32 & 0 \\
England & & \\
All strains & 110 & 34 \\
C. paraputrificum & 37 & 81 \\
C. indolis & 18 & 28 \\
Others & 55 & 4 \\
Uganda & & 7 \\
All strains & 54 & 0 \\
C. paraputrificum & 4 & 0 \\
C. indolis & 3 & \\
Others & 47 & 12 \\
Hong Kong. & & 7 \\
All strains & 16 & \\
C. paraputrificum & 1 & \\
C. indolis & 0 & \\
Others & 15 & \\
\hline
\end{tabular}


interest and these are $C$. paraputrificum and $C$. indolis. In British faeces these two species accounted for approximately $50 \%$ of the lecithinase-negative clostridia present, and a large proportion (more than $30 \%$ ) of strains were able to dehydrogenate the steroid nucleus (table II). In contrast, only a small proportion of strains of clostridia in faeces from Uganda and Hong Kong belonged to these species and the proportion of strains with NDH activity was low.

\section{Modification of the assay for $\Delta^{4}$-dehydrogenase}

The assay system used to date to determine steroid $\Delta^{4}$-dehydrogenase is unsatisfactory because it involves a prolonged incubation period, and it is carried out aerobically and therefore does not simulate conditions in the gut. We have therefore looked for ways of making the assay system less timeconsuming and also of making the system anaerobic.

All strains able to carry out this reaction that have been detected so far in human faeces have been clostridia, and these organisms are known to carry out mixed fermentations in which the oxidation of a substrate is linked to the reduction of a second substrate; this allows oxidative reactions to take place in the absence of oxygen. An example of this is the Stickland reaction for aminoacid deamination.

We tested two reductive reactions-the reduction of nitrate and of vitamin $\mathrm{K}_{3}$ (menadione). Most of the strains of $C$. paraputrificum that we tested reduced nitrate weakly, but when nitrate was added to the $\Delta^{4}$-dehydrogenase assay system it was reduced to nitrite very rapidly, and this was accompanied by a dehydrogenation of the steroid substrate even under anaerobic conditions; the same amount of dehydrogenation was achieved in $24 \mathrm{~h}$ in the presence of nitrate as occurred in $72 \mathrm{~h}$ in its absence. However, if the reaction mixture was left for longer periods in the anaerobic environment, the dehydrogenation reaction began to reverse and by $72 \mathrm{~h}$ no unsaturated product remained.

In the presence of menadione, again the yield of unsaturated product within $24 \mathrm{~h}$ under anaerobic conditions was greater than that obtained aerobically in the absence of menadione in $72 \mathrm{~h}$. Although there was a tendency for the reaction to go into reverse subsequently this was of minor importance; accordingly, in this case the time at which the reaction mixture was analysed was not critical.

In the light of these results the assay system has now been modified. Organisms are grown in $25 \mathrm{ml}$ of Todd-Hewitt broth containing $1 \mathrm{mg}$ of $5 \beta$-androstan-3,17-dione for $24 \mathrm{~h}$ at $37^{\circ} \mathrm{C}$ in an atmosphere of $25 \% \mathrm{CO}_{2}$ with $75 \% \mathrm{H}_{2}$. A further $5 \mathrm{mg}$ of $5 \beta$-androstan-3,17-dione substrate and $35 \mathrm{mg}$ of menadione are then added and the reaction mixture is incubated anaerobically for a further $24 \mathrm{~h}$ at $37^{\circ} \mathrm{C}$. The mixture is extracted twice with $25 \mathrm{ml}$ of chloroform, the extracts pooled and concentrated to $0.5 \mathrm{ml}$ by evaporation and analysed by thin-layer chromatography as previously described.

This modification postdates the results reported here; however, in subsequent comparative tests the results obtained with the original method and with this modification were identical. 


\section{Discussion}

These screening studies indicate the relative importance of the various genera of intestinal organisms in the NDH of steroids. Previous studies of one of the reactions-the 7-dehydroxylation step, in which 6-7 dehydration is the first stage-showed that a two-stage enzyme is evenly distributed amongst the non-sporing and spore-forming anaerobic organisms (Hill et al., 1971). Because the non-sporing strictly anaerobic organisms are so numerically dominant in the gut, it is unlikely that the enzyme produced by the clostridia is of primary significance in the nuclear dehydration of bile acids in the human intestine.

It would be necessary to screen 10,000 non-sporing anaerobes unsuccessfully before it could be claimed with certainty that only the clostridia are of importance in the other NDH reactions. This is obviously not practicable, but we believe that our results at least strongly indicate that the latter conclusion is valid. An oxidation reaction of this type would not be expected of a strictly anaerobic organism, and perhaps the ability of clostridia to carry out linked oxidation-reduction reactions permits them to dehydrogenate steroids in the absence of oxygen. The clostridia that perform nuclear dehydrogenation are here referred to as NDH clostridia.

The important question is to determine the nature of the natural hydrogen acceptor in the gut. The nitrate reductase system provides an adequate hydrogen acceptor, but we believe that no nitrate reaches the large intestine (Hill and Hawksworth, 1974). Vitamin K promotes the NDH reaction and is known to be present in the large bowel, presumably in the form of vitamin $\mathrm{K}_{2}$ : we suspect that the vitamin $K_{1}$, derived from plants in the diet, is absorbed from the small intestine so that only the vitamin produced by the gut bacteria, $\mathrm{K}_{2}$, will be present in the colon; however we can find no data on this.

Most of the strains able to carry out reaction A were also able to carry out reaction $\mathbf{B}$, whereas no organism able to perform reaction $\mathbf{B}$ was unable to perform reaction $A$. Superficially these are two entirely different types of reaction and the result was therefore surprising; we can offer no explanation for it. Too few assays of reaction $C$ have been made, but our findings so far indicate that all strains able to carry out this reaction are also able to carry out reactions $\mathbf{A}$ and $\mathbf{B}$. As reaction $\mathbf{C}$ is very similar to reaction $\mathbf{A}$ this result is less surprising. A practical conclusion is that it is only necessary to screen for one of the three enzymes in order to have a guide to the production of all three. Enzyme $A$ is the most cheaply and easily assayed of the three.

If the production of unsaturated bile acids by NDH clostridia is important in the development of cancer of the human colon, then people with both a high faecal bile-acid concentration and large numbers of NDH clostridia in their faeces should be at high risk from colon cancer. We intend to carry out screening studies to test this; the present preliminary study indicates that in people living in Britain-a country in which the incidence of cancer of the colon is relatively high-more than $30 \%$ of the faecal lecithinase-negative clostridia produce NDH enzymes. On the other hand, we have found only a small 
percentage of such clostridia in faeces of people living in countries with a low incidence of colon cancer.

To expedite such screening studies we are attempting to simplify the enzyme assay procedure. Whilst the method reported here is a considerable improvement on the original assay and could be used to screen hundreds of strains, it is still not suitable for screening thousands.

\section{SUMMARY}

We have postulated that bacteria able to dehydrogenate the bile-acid nucleus are important in the aetiology of cancer of the colon. In this paper we report on screening for the ability to carry out two such reactions. The relevant enzymes are produced by a high proportion of strains of Clostridium paraputrificum, $C$. tertium and $C$. indolis, and by small numbers of strains in other clostridial species, but not by organisms of the other genera tested. Strains able to dehydrogenate the bile-acid nucleus represent a high proportion of the lecithinase-negative clostridia isolated from faeces of people living in Britain but a low proportion of those from people living in Uganda or Hong Kong.

We wish to acknowledge the financial support of the Cancer Research Campaign.

\section{REFERENCES}

Aries, V. C., Crowther, J. S., Drasar, B. S., Hill, M. J. and Williams, R. E. O. 1969. Bacteria and the aetiology of cancer of the large bowel. Gut, 10, 334.

Aries, V. C., Goddard, P. ANd Hill, M. J. 1971. Degradation of steroids by intestinal bacteria. III. 3-oxo-5 $\beta$-steroid $\Delta^{1}$ dehydrogenase and 3-oxo-5 $\beta$-steroid $\Delta^{4}$ dehydrogenase. Biochim. biophys. Acta, 248, 482.

CowAN, S. T. AND STeEL, K. J. 1965. Manual for the identification of medical bacteria, London.

Drasar, B. S. AND Crowther, J. S. 1970. The cultivation of human intestinal bacteria. In Isolation of anaerobes, Soc. appl. Bact. Tech. Ser. no. 5, edited by D. A. Shapton and R. G. Board, London, p. 93.

Drasar, B. S., Goddard, P., Heaton, S., Peach, S., and West, B. (1976). Clostrida isolated from faeces. J. med. Microbiol., 9, in press.

Goddard, P. AND HILL, M. J. 1972. Degradation of steroids by intestinal bacteria. IV. The aromatisation of ring A. Biochim. biophys. Acta, 280, 336.

GodDARD, P. AND HILL, M. J. 1973. The dehydrogenation of the steroid nucleus by human gut bacteria. Biochem. Soc. Trans., 1, 1113.

HiLl, M. J. 1971. Gut bacteria, steroids and cancer of the large bowel. In Some implications of steroid hormones in cancer, edited by D. C. Williams and M. H. Briggs, London, p. 94.

Hill, M. J., Drasar, B. S., Aries, V., Crowther, J. S., Hawksworth, G. and Williams, R. E. O. 1971. Bacteria and aetiology of cancer of the large bowel. Lancet, 1, 95.

HiLl, M. J. AND HawkswORTH, G. M. 1972. Bacterial production of nitrosamines in vitro and in vivo. In $\mathrm{N}$-nitroso compounds analysis and formation, IARC Sci. Pub. no. 3, edited by P. Bogovski, R. Preussman and E. A. Walker, Lyons, p. 116.

Holdeman, L. V. and MoORe, W. E. C. (Editors) 1972. Anaerobe laboratory manual, Blacksburg, Virginia.

Peach, S., Fernandez, F., Johnson, K. And Drasar, B. S. 1974. The non-sporing anaerobic bacteria in human faeces. J. med. Microbiol., 7, 213.

SeHgal, S. N. AND Vezina, C. 1970 . Microbial aromatisation of steroids into equilin. Appl. Microbiol., 20, 875. 